\title{
Design Patterns for Augmented Reality Learning Games
}

\author{
Citation for published version (APA):
}

Emmerich, F., Klemke, R., \& Hummes, T. (2017). Design Patterns for Augmented Reality Learning Games. In J. D., P. A. S., \& R. C. V. (Eds.), Games and Learning Alliance: 6th International Conference, GALA 2017, Lisbon, Portugal, December 5-7, 2017, Proceedings (Vol. 10653, pp. 161-172). Springer. Lecture Notes in Computer Science https://doi.org/10.1007/978-3-319-71940-5_15

\section{DOI:}

10.1007/978-3-319-71940-5_15

Document status and date:

Published: 01/12/2017

Document Version:

Peer reviewed version

\section{Document license:}

CC BY-NC-SA

Please check the document version of this publication:

- A submitted manuscript is the version of the article upon submission and before peer-review. There can be important differences between the submitted version and the official published version of record. People interested in the research are advised to contact the author for the final version of the publication, or visit the DOI to the publisher's website.

- The final author version and the galley proof are versions of the publication after peer review.

- The final published version features the final layout of the paper including the volume, issue and page numbers.

Link to publication

\section{General rights}

Copyright and moral rights for the publications made accessible in the public portal are retained by the authors and/or other copyright owners and it is a condition of accessing publications that users recognise and abide by the legal requirements associated with these rights.

- Users may download and print one copy of any publication from the public portal for the purpose of private study or research.

- You may not further distribute the material or use it for any profit-making activity or commercial gain

- You may freely distribute the URL identifying the publication in the public portal.

If the publication is distributed under the terms of Article 25fa of the Dutch Copyright Act, indicated by the "Taverne" license above, please follow below link for the End User Agreement:

https://www.ou.nl/taverne-agreement

Take down policy

If you believe that this document breaches copyright please contact us at:

pure-support@ou.nl

providing details and we will investigate your claim.

Downloaded from https://research.ou.nl/ on date: 26 Apr. 2023 


\title{
Design Patterns for Augmented Reality Learning Games
}

\author{
Felix Emmerich ${ }^{1}$, Roland Klemke ${ }^{1,2}$, Thomas Hummes ${ }^{1}$ \\ ${ }^{1}$ Mediadesign Hochschule, Faculty of Gamedesign, Düsseldorf, Germany \\ ${ }^{2}$ Welten Institute, Open University of the Netherlands, Heerlen, Netherlands \\ fnemmerich@gmail.com, Roland.Klemke@ou.nl,Thomas.Hummes@gmail.com
}

\begin{abstract}
Augmented Reality (AR) is expected to receive a major uptake with the recent availability of high quality wearable AR devices such as Microsoft's Hololens. However, the design of interaction with AR applications and games is still a field of experimentation and upcoming innovations in sensor technology provide new ways. With this paper, we aim to provide a step towards the structured use of design patterns for sensor-based AR games, which can also inform general application development in the field of AR.
\end{abstract}

Keywords. Augmented Reality, Game-design Patterns, Interaction Patterns, Learning Games

\section{Introduction}

"The convergence of mobile computing and wearable computing with augmented reality is naturally of great interest to interaction designers" [1], while "the convergence of wearable computing, wireless networking and mobile AR interfaces" is bringing "a new breed of computing called 'augmented ubiquitous computing" [2].

Augmented Reality (AR) can be defined as "the fusion of any digital information with physical world settings, i.e. being able to augment one's immediate surroundings with electronic data or information, in a variety of formats including visual/graphic media, text, audio, video and haptic overlays" [3]. Features, "most of which are present in most AR systems" [4] are listed as: "Sense properties about the real world; process in real time; output (overlay) information to the user; provide contextual information; recognize and track real-world objects; be mobile or wearable" [4].

Examples of AR systems utilizing senses other than sight include [5], whose application for cultural sciences students' field trips focused on audio augmentation, arguing that "just like a user should - while driving a car - use sight as much as possible to drive, we believe that with location based learning, a learner's eyes must be primarily used to examine the environment". Haptic feedback corresponding to virtual objects may be transferred from Virtual Reality to AR [6].

Location-based AR outputs information based on the user's position $[3,7,8]$. Points of Interest (POI) are defined and associated with virtual assets - "when a user [...] explores a space the POIs are revealed and the content can be accessed" [8]. $V$ ision-based AR functions by using computer vision techniques to identify and track patterns known as fiducials (visual markers [9]) in the environment [3, 8]. Both of these approaches have their advantages and disadvantages: Fiducials can only be used with systems trained to recognize them and if conditions like inadequate lighting do

Preprint version. Cite this paper as: Emmerich F., Klemke R., Hummes T. (2017) Design Patterns for Augmented Reality Learning Games. In: Dias J., Santos P., Veltkamp R. (eds) Games and Learning Alliance. GALA 2017. Lecture Notes in Computer Science, vol 10653. Springer, Cham 
not interfere. Location-based systems can suffer from inaccuracy or loss of tracking [10].

A way to combine the advantages of both approaches may lie in hybrid systems as described by [11] or image understanding [12]. The Microsoft HoloLens utilizes a depth camera and tracks head movements through various sensors. A technique called "spatial mapping" [13] is used to construct a three-dimensional model of the surroundings and display virtual content at the appropriate coordinates.

Design patterns for general interaction [14] and games exist [15] and high-level patterns for Mixed Reality games have been proposed [16]. We aim to close the gap between low-level interactions in sensor-based wearable AR systems and high-level game-design patterns for learning games by providing a framework of design patterns for AR games. While such a framework can generally be applied to all kinds of AR games, our main target is to guide the construction of AR learning games. However, pedagogical in relation to the design patterns are not in the focus of this research. Instead, here our focus is more on interactivity and visualization. Definitions, approaches, potentials and limitations of AR are presented, followed by our framework and its first prototypical implementation.

\section{Augmented Reality for Learning games}

AR has been applied to many domains, including "hands-free instruction and training, language translation, obstacle avoidance, advertising, gaming, museum tours, and much more" [4], maintenance and repair [17], or Big Data visualization [18], where AR "might solve many issues from narrow visual angle, navigation, scaling, etc.".

Games are an application particularly well-suited for the medium of AR, as "augmented reality is an active, not a passive technology" [7], which emphasizes the "dialogue between the media and the context in which it is used" [3]. Although commercial AR games can be said to go back as far as 2003's EyeToy [10], efforts were for a long time focused on research, until the advance of smartphone technology, which made devices with AR capabilities widely available [16].

Pokémon GO [19], an AR game based on both, the well-known Pokémon franchise and Ingress [20], is a rare example of a mobile AR game with a large player base. In the field of learning games [21] reports that Mixed Reality games offer the opportunity to "sense and feel being 'someone' else", while first person experiences make it challenging to develop empathy. Locatory is an AR adaptation of the game Memory, requiring players to find virtual cards spread around the environment and then match them to real landmarks, to foster orientation skills [22].

Game design patterns have been used to map cognitive and affective learning outcomes in AR games for learning [23]. Similarly, a recent literature review identifies three design principles for learning-oriented AR - "enable and then challenge," "drive by gamified story," and "see the unseen" [24].

Knowledge about how to best approach the design of AR games is still lacking [16], a sentiment [25] shares: "Little is known on how to systematically apply gamedesign patterns to augmented reality". Similarly to these, [24] attempts to extrapolate design guidelines from the AR game Dino Dig, which despite having educational content was primarily intended to entertain. 


\section{Design Patterns for AR-based Games}

Design patterns describe precisely how to use design techniques in order to achieve certain positive effects, at the same time providing insight and creating a shared vocabulary in the form of a pattern language $[16,26]$. More precisely, design patterns "express a relationship between particular design contexts, forces [...], and desired ('positive' or good) features" [26].

Björk and Holopainen [27] collected game design patterns, concerned with idea generation. General characteristics of patterns can be outlined as: "Operational and precise"; "positive"; "flexible"; "debatable (the Pattern is clear enough to criticize)"; "testable"; "end-user oriented." [26]. A well-defined game design pattern language would allow for efficient communication, documentation and analysis "e.g. for purposes of comparative criticism, re-engineering, or maintenance" [28].

The patterns collected by Björk \& Holopainen [27] do not utilize a problemsolution approach, with Björk, Lundgren, \& Holopainen arguing that "not all aspects of design can or should be seen as solving problems, especially in a creative activity such as game design" [15]. The Game Ontology Project describes, analyzes and studies games with pattern-like entries existing in a hierarchy the top level of which includes interface, rules, entity manipulation, and goals [29]. More on the pedagogical side [30] define a framework for the construction of learning games.

The literature revealed only a few pattern approaches for the domain of AR, mainly as interaction patterns. The examples below are presented informally but fit characteristics from [26]. They provide data, which the framework presented in this paper was able to expand on and have thus been included.

The Point Of Interest (POI) interaction pattern is often implemented in mobile AR browsers. When arriving at pre-defined points, users receive information about the environment through a choice of channels [5]. Browsers may also direct the user towards nearby points of interest [3]. The Head-Up Display (HUD) presents information from a fixed point of view, i.e. the information is not assigned some coordinate in 3D space [1]. The Tricorder interaction pattern refers to scenarios in which information is scanned from the environment, adding "pieces of information to an existing real-world experience" [1]. Holochess experiences consist of presenting entirely virtual objects to the AR environment. $X$-Ray Vision-based experiences allow "seeing beneath the surface of objects, people, or places" [1].

Design patterns for mobile games have been mapped to cognitive and motivational effects in educational AR games [31]. A short, preliminary list of patterns "which take advantage of AR potential" comprising names and short descriptions consists of: Localization, video recording and view sharing, synchronous communication, contextualization, and object recognition [25]. There are still challenges for AR to overcome, which inform the framework for interactions in AR in the remainder of this paper, applying a pattern approach, incorporating elements from the various sources discussed above, while adhering to the general characteristics laid out by [26].

\section{A Pattern-based Framework for AR Learning Games}

Our pattern-based framework, mirroring above-mentioned approaches to game design patterns, is a classification of possible interactions, akin to the game mechanic terminology.

Method. The framework and the software development are based on design patterns, which we defined according to the various approaches presented above [14, 16, 25-28]. Technologically, we build on the comparison of available AR systems 
and sensors performed by [32]. In this first iteration of the framework, the pattern elements that were used in at least three of the six papers are present. They are:

Name: A succinct name for the pattern.

Forces/Problem: The issues the pattern is intended to combat.

Feature/Solution: A description of one way to solve the problem.

Effects/Consequences: The positive and negative consequences of applying the pattern, including design choices required for implementing the pattern.

Requirements: We introduced requirements, which must or may be met to implement a pattern. This allows game designers interested in implementing patterns to ascertain whether a given pattern fits their criteria.

Scope. Challenges to AR can roughly be sorted into those pertaining to technology, user interface and social acceptance [33]. Due to the scope of this paper and the framework's focus on the interactive medium of games, of these only user interfaces - visualization and interaction - will be covered. Additionally, some patterns focus on the development side of AR applications. The content of the patterns listed below is derived from the literature mentioned, a brainstorming session with participants of the WEKIT project [34], and the characteristics of existing AR games acquired through play testing. We grouped the patterns into six groups: directional, environmental, input, non-visual feedback, media-related, and multi-user, displayed in table 1 .

Table 1. Basic Patterns

\begin{tabular}{|c|c|c|c|c|c|}
\hline & Pattern & Forces/Problem & Feature/Solution & Effects/Consequences & Requirements \\
\hline \multirow{2}{*}{ 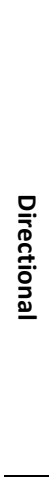 } & $\begin{array}{l}\text { Directed } \\
\text { Gaze }\end{array}$ & $\begin{array}{l}\text { Direct a user's } \\
\text { attention to } \\
\text { something when } \\
\text { they have full } \\
\text { control over } \\
\text { their view. }\end{array}$ & $\begin{array}{l}\text { Use icon to direct } \\
\text { user attention. Icon } \\
\text { points to the object } \\
\text { of interest, if it is not } \\
\text { currently visible. }\end{array}$ & $\begin{array}{l}\text { Structure AR experience, } \\
\text { guide user. Combinable } \\
\text { with Gaze Cursor. May } \\
\text { obstruct other elements } \\
\text { and cause screen clutter. } \\
\text { Multiple focus points } \\
\text { require Inf. Filtering. }\end{array}$ & $\begin{array}{l}\text { System needs } \\
\text { awareness of } \\
\text { the focus point } \\
\text { position } \\
\text { relative to user } \\
\text { location and } \\
\text { head rotation. }\end{array}$ \\
\hline & $\begin{array}{l}\text { Directed } \\
\text { Move- } \\
\text { ment }\end{array}$ & $\begin{array}{l}\text { Applications may } \\
\text { require the user } \\
\text { to move to } \\
\text { certain locations. }\end{array}$ & $\begin{array}{l}\text { Display icon at the } \\
\text { target location. Icon } \\
\text { points to the target } \\
\text { location, if it is not } \\
\text { currently visible. }\end{array}$ & $\begin{array}{l}\text { Structures AR experience } \\
\text { and guides users. May } \\
\text { obstruct other elements } \\
\text { and cause screen clutter. } \\
\text { Multiple focus points } \\
\text { require Information } \\
\text { Filtering. }\end{array}$ & $\begin{array}{l}\text { System needs } \\
\text { awareness of } \\
\text { the focus point } \\
\text { position } \\
\text { relative to user } \\
\text { location and } \\
\text { head rotation. }\end{array}$ \\
\hline \multirow{3}{*}{ 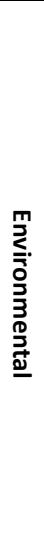 } & $\begin{array}{l}\text { Environ- } \\
\text { ment- } \\
\text { Adapta- } \\
\text { tion }\end{array}$ & $\begin{array}{l}\text { Design a game } \\
\text { that can be run } \\
\text { anywhere, while } \\
\text { taking the } \\
\text { environment } \\
\text { into account }\end{array}$ & $\begin{array}{l}\text { Make the game } \\
\text { automatically adapt } \\
\text { to the characteristics } \\
\text { of the environment. }\end{array}$ & $\begin{array}{l}\text { The game will run in many } \\
\text { environments while making } \\
\text { use of AR. Games cannot be } \\
\text { planned as stringently and } \\
\text { different users may have } \\
\text { different experiences. }\end{array}$ & $\begin{array}{l}\text { System needs } \\
\text { awareness of } \\
\text { surrounding. } \\
\text { Depth sensors, } \\
\text { cameras may } \\
\text { be sufficient. }\end{array}$ \\
\hline & $\begin{array}{l}\text { Environ- } \\
\text { ment- } \\
\text { Inde- } \\
\text { pen- } \\
\text { dence }\end{array}$ & $\begin{array}{l}\text { How can you } \\
\text { develop AR } \\
\text { games for } \\
\text { unknown } \\
\text { environments? }\end{array}$ & $\begin{array}{l}\text { Make the game not } \\
\text { interact with the } \\
\text { environment. }\end{array}$ & $\begin{array}{l}\text { Games will function more } \\
\text { reliably and predictably. } \\
\text { User enjoyment may be } \\
\text { reduced due to missing AR } \\
\text { experience. }\end{array}$ & $\begin{array}{l}\text { Games should } \\
\text { function } \\
\text { without extra } \\
\text { sensors. }\end{array}$ \\
\hline & $\begin{array}{l}\text { Environ } \\
\text { ment } \\
\text { Require } \\
\text { ments }\end{array}$ & $\begin{array}{l}\text { Game interacts } \\
\text { with different } \\
\text { environments } \\
\text { without changing } \\
\text { the game itself. }\end{array}$ & $\begin{array}{l}\text { Make the game's } \\
\text { environmental } \\
\text { requirements } \\
\text { explicit. }\end{array}$ & $\begin{array}{l}\text { Ensures that AR game } \\
\text { works as intended. Possibly } \\
\text { requires user to make } \\
\text { changes to their environ- } \\
\text { ment to play the game. }\end{array}$ & $\begin{array}{l}\text { Requirements } \\
\text { must be } \\
\text { explained and } \\
\text { checked. }\end{array}$ \\
\hline
\end{tabular}




\begin{tabular}{|c|c|c|c|c|c|}
\hline & $\begin{array}{l}\text { Point of } \\
\text { Interest } \\
\text { (POI) }\end{array}$ & $\begin{array}{l}\text { Provide } \\
\text { information to } \\
\text { users based on } \\
\text { location. Bind } \\
\text { information to } \\
\text { locations not } \\
\text { accessible.. }\end{array}$ & $\begin{array}{l}\text { Bind information to } \\
\text { locations, making it } \\
\text { available upon } \\
\text { getting within a } \\
\text { certain range and } \\
\text { allowing to direct } \\
\text { users to such points. }\end{array}$ & $\begin{array}{l}\text { Multiple POls should not } \\
\text { overlap or the system must } \\
\text { handle overlap. Avoid } \\
\text { screen clutter. Precision is } \\
\text { low if only location data is } \\
\text { used - may be combined or } \\
\text { replaced with a Gaze POI. }\end{array}$ & $\begin{array}{l}\text { Requires } \\
\text { location } \\
\text { technology. }\end{array}$ \\
\hline \multirow{4}{*}{$\begin{array}{l}\bar{z} \\
\frac{0}{7} \\
\frac{1}{1} \\
\frac{1}{2} \\
\frac{1}{2} \\
\frac{\mathbb{0}}{2}\end{array}$} & $\begin{array}{l}\text { Gaze } \\
\text { Cursor }\end{array}$ & $\begin{array}{l}\text { How do you } \\
\text { select the object } \\
\text { to apply actions } \\
\text { to? }\end{array}$ & $\begin{array}{l}\text { Base actions on gaze, } \\
\text { indicated with visual } \\
\text { cursor. Select } \\
\text { objects, complete } \\
\text { actions (e.g. based on } \\
\text { gaze duration). }\end{array}$ & $\begin{array}{l}\text { Guide interactions. } \\
\text { Inaccurate or lagging } \\
\text { cursors may mislead. Cursor } \\
\text { might obscure object of } \\
\text { interest. Tunnel vision may } \\
\text { be provoked. }\end{array}$ & $\begin{array}{l}\text { Awareness of } \\
\text { the user's gaze } \\
\text { required. }\end{array}$ \\
\hline & $\begin{array}{l}\text { Gaze } \\
\text { Point of } \\
\text { Interest } \\
\text { (Gaze } \\
\text { POI) }\end{array}$ & $\begin{array}{l}\text { How can events } \\
\text { in AR be } \\
\text { triggered? }\end{array}$ & $\begin{array}{l}\text { Perform actions } \\
\text { when the player } \\
\text { looks at specific } \\
\text { objects (real or } \\
\text { virtual). Events may } \\
\text { indicate when } \\
\text { something leaves or } \\
\text { enters field of view. }\end{array}$ & $\begin{array}{l}\text { Focus on important } \\
\text { information, context- } \\
\text { sensitive information. } \\
\text { Combine with Gaze Cursor } \\
\text { to show selected objects. In } \\
\text { larger areas, POI may be } \\
\text { used. Unintended events } \\
\text { may be confusing. }\end{array}$ & $\begin{array}{l}\text { Gaze direction } \\
\text { and } \\
\text { environmental } \\
\text { model } \\
\text { required. }\end{array}$ \\
\hline & $\begin{array}{l}\text { Gesture- } \\
\text { based } \\
\text { Inter- } \\
\text { action }\end{array}$ & $\begin{array}{l}\text { Interact } \\
\text { intuitively with } \\
\text { AR environment. }\end{array}$ & $\begin{array}{l}\text { Allow the } \\
\text { manipulation of } \\
\text { objects through } \\
\text { gestures. }\end{array}$ & $\begin{array}{l}\text { Without special input } \\
\text { devices, AR systems may be } \\
\text { more immersive and } \\
\text { intuitive. Non-intuitive or } \\
\text { accidental inputs can be } \\
\text { frustrating. }\end{array}$ & $\begin{array}{l}\text { Hand } \\
\text { movement } \\
\text { tracking and } \\
\text { gesture } \\
\text { recognition } \\
\text { required. }\end{array}$ \\
\hline & $\begin{array}{l}\text { Voice } \\
\text { Com- } \\
\text { mands }\end{array}$ & $\begin{array}{l}\text { How do you } \\
\text { allow user input } \\
\text { while keeping } \\
\text { the user's hands } \\
\text { free? }\end{array}$ & $\begin{array}{l}\text { Enables the user to } \\
\text { perform actions by } \\
\text { speaking appropriate } \\
\text { phrases. }\end{array}$ & $\begin{array}{l}\text { Can enhance user } \\
\text { experience. Simple phrases } \\
\text { to avoid frustration. May } \\
\text { face acceptance issues in } \\
\text { shared spaces. }\end{array}$ & $\begin{array}{l}\text { Requires one } \\
\text { or more } \\
\text { microphones. }\end{array}$ \\
\hline 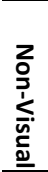 & $\begin{array}{l}\text { Haptic } \\
\text { Feed- } \\
\text { back }\end{array}$ & $\begin{array}{l}\text { Receive feedback } \\
\text { when "touching" } \\
\text { augmented } \\
\text { objects. }\end{array}$ & $\begin{array}{l}\text { Give feedback via the } \\
\text { haptic sense. Users } \\
\text { may be more } \\
\text { responsive to non- } \\
\text { visual feedback. }\end{array}$ & $\begin{array}{l}\text { Feedback device can limit } \\
\text { freedom of movement. } \\
\text { Inappropriate feedback may } \\
\text { break immersion. }\end{array}$ & $\begin{array}{l}\text { Additional } \\
\text { feedback } \\
\text { channels via } \\
\text { feedback } \\
\text { devices }\end{array}$ \\
\hline \multirow{3}{*}{$\begin{array}{l}3 \\
\frac{3}{0} \\
\frac{0}{0} \\
\frac{1}{1} \\
\frac{0}{0} \\
\frac{0}{2} \\
\frac{1}{0} \\
0\end{array}$} & $\begin{array}{l}\text { Auto- } \\
\text { Play }\end{array}$ & $\begin{array}{l}\text { Trigger events in } \\
\text { AR without } \\
\text { requiring or } \\
\text { despite varying } \\
\text { kinds of user } \\
\text { input. }\end{array}$ & $\begin{array}{l}\text { Automatically } \\
\text { starting, pausing, } \\
\text { and/or stopping } \\
\text { events (e.g. based on } \\
\text { location/gaze). }\end{array}$ & $\begin{array}{l}\text { Help to avoid tunnel vision } \\
\text { and to increase pleasure. } \\
\text { Automatic warnings can } \\
\text { prevent injury or incorrect } \\
\text { use. Can confuse or cause } \\
\text { screen clutter. Needs way } \\
\text { to stop unwanted content. }\end{array}$ & $\begin{array}{l}\text { Auto-Play may } \\
\text { be based on } \\
\text { position, gaze, } \\
\text { orientation, } \\
\text { audio input, or } \\
\text { fiducials. }\end{array}$ \\
\hline & $\begin{array}{l}\text { Infor- } \\
\text { mation } \\
\text { Filtering }\end{array}$ & $\begin{array}{l}\text { Screen clutter by } \\
\text { too much } \\
\text { information. Too } \\
\text { little reduces } \\
\text { usefulness. }\end{array}$ & $\begin{array}{l}\text { Filter information e.g. } \\
\text { by distance, angle, or } \\
\text { relevance-based } \\
\text { information. }\end{array}$ & $\begin{array}{l}\text { Makes systems easier to } \\
\text { use. Ensure that the filter } \\
\text { reflects the intention to } \\
\text { avoid too little or too much } \\
\text { information. }\end{array}$ & $\begin{array}{l}\text { Required } \\
\text { sensors } \\
\text { depend on the } \\
\text { exact filter } \\
\text { approach. }\end{array}$ \\
\hline & $\begin{array}{l}\text { Ob- } \\
\text { scured } \\
\text { Infor- } \\
\text { mation } \\
\text { Visuali- } \\
\text { zation }\end{array}$ & $\begin{array}{l}\text { Keep track of } \\
\text { content that is } \\
\text { hidden behind } \\
\text { other objects, } \\
\text { real or virtual, at } \\
\text { a given time. }\end{array}$ & $\begin{array}{l}\text { Visualize an object } \\
\text { even, or specifically, } \\
\text { if it is obscured } \\
\text { (various approaches). }\end{array}$ & $\begin{array}{l}\text { Can afford the user a better } \\
\text { understanding of their } \\
\text { (augmented) environment. } \\
\text { However, inappropriate } \\
\text { approaches may cause } \\
\text { depth perception issues. }\end{array}$ & $\begin{array}{l}\text { Tracking of } \\
\text { real and AR } \\
\text { objects, } \\
\text { tracking head } \\
\text { and } \\
\text { environments. }\end{array}$ \\
\hline
\end{tabular}




\begin{tabular}{|c|c|c|c|c|c|}
\hline$\frac{3}{\frac{3}{5}}$ & $\begin{array}{l}\text { Shared } \\
\text { Pointer }\end{array}$ & $\begin{array}{l}\text { How can } \\
\text { multiple people } \\
\text { in an AR } \\
\text { environment } \\
\text { communicate } \\
\text { efficiently? }\end{array}$ & $\begin{array}{l}\text { Use (gaze) cursors, } \\
\text { also visible to other } \\
\text { players or allow users } \\
\text { to leave markers at } \\
\text { set points. }\end{array}$ & $\begin{array}{l}\text { Allow users to } \\
\text { communicate easily. } \\
\text { Requires directed user input } \\
\text { (e.g. Gaze Cursor). See } \\
\text { Directed Gaze and Directed } \\
\text { Movement. }\end{array}$ & $\begin{array}{l}\text { Positions and } \\
\text { orientations of } \\
\text { users must be } \\
\text { tracked and } \\
\text { synch"d in } \\
\text { real-time. }\end{array}$ \\
\hline
\end{tabular}

\section{Combined patterns for AR Learning Games}

The idea of the framework described above is twofold:

(1) We aim to work towards a best practice collection of patterns, which enable players of AR learning games to intuitively understand interaction mechanisms. This aspect has been presented in the review of existing AR games and the patterns found within, which found its place in the effects/consequences column of each pattern.

(2) We want to provide a design toolbox, enabling game designers and developers to construct complex games utilising and combining the basic patterns described. This section is about the second aspect. In line with [27], we see our pattern collection as part of a more general game design language. In this sense, not only should the patterns described here be combinable with each other, but also should a game designer be enabled to combine these patterns with patterns from other collections, such as those reviewed above. Consequently, we see the examples of proposed pattern combinations presented below as a demonstration of the possible use of our framework (table 2).

Table 2. Combined Patterns usable for learning games

\begin{tabular}{|c|c|c|c|}
\hline Pattern & Forces/Problem & Feature/Solution & Effects/ Consequences \\
\hline $\begin{array}{l}\text { Exten- } \\
\text { ded } \\
\text { Room }\end{array}$ & $\begin{array}{l}\text { The gameplay may } \\
\text { require additional } \\
\text { virtual rooms, spaces, } \\
\text { and structures. }\end{array}$ & $\begin{array}{l}\text { Obscured Information Visualization, } \\
\text { Environment Requirements, and } \\
\text { Environment Adaptation enable } \\
\text { virtual objects to overlay physical } \\
\text { structures (e.g. showing non-existing } \\
\text { rooms). "Magic Doors" allow to } \\
\text { virtually enter a different room. }\end{array}$ & $\begin{array}{l}\text { Useful e.g. for historic } \\
\text { learning (what did a scene } \\
\text { look like previously) or for } \\
\text { change planning (what } \\
\text { might it look in future). Also } \\
\text { useful for virtual travels. }\end{array}$ \\
\hline $\begin{array}{l}\text { Explo- } \\
\text { ration } \\
\text { and } \\
\text { Search }\end{array}$ & $\begin{array}{l}\text { Virtual Objects should } \\
\text { be hideable } \\
\text { behind/under physical } \\
\text { objects to force the } \\
\text { player to search them } \\
\text { within the physical } \\
\text { environment. }\end{array}$ & $\begin{array}{l}\text { Based on Obscured Information } \\
\text { Visualization, Information Filtering, } \\
\text { Environment Requirements, } \\
\text { Environment Adaptation from this } \\
\text { collection and Exploration, Clues. } \\
\text { Optional hints can be used for } \\
\text { guidance. }\end{array}$ & $\begin{array}{l}\text { Explorative learning tasks to } \\
\text { foster orientation, } \\
\text { exploration strategy }\end{array}$ \\
\hline $\begin{array}{l}\text { Asym- } \\
\text { metric } \\
\text { Multi- } \\
\text { player }\end{array}$ & $\begin{array}{l}\text { Two players require } \\
\text { different information, } \\
\text { e.g. according to } \\
\text { individual roles, } \\
\text { locations, or progress. }\end{array}$ & $\begin{array}{l}\text { Based on Information Filtering, } \\
\text { Shared Pointer from this collection } \\
\text { and Asymmetric Information } \\
\text { information can be individualized. }\end{array}$ & $\begin{array}{l}\text { Asymmetric information } \\
\text { can be bound to teacher/ } \\
\text { learner roles or to reflect } \\
\text { individual learning needs }\end{array}$ \\
\hline $\begin{array}{l}\text { Aug- } \\
\text { mented } \\
\text { Ghost } \\
\text { Track }\end{array}$ & $\begin{array}{l}\text { A player can see and } \\
\text { follow the track of } \\
\text { another player in the } \\
\text { physical environment }\end{array}$ & $\begin{array}{l}\text { Shared Pointer, Information Filtering, } \\
\text { Directed Gaze, Directed Movement } \\
\text { can be combined to create ghost } \\
\text { tracks. }\end{array}$ & $\begin{array}{l}\text { A learner can follow guided } \\
\text { steps or work on } \\
\text { continuous improvement of } \\
\text { own ghost track data. }\end{array}$ \\
\hline $\begin{array}{l}\text { X-Ray } \\
\text { Vision }\end{array}$ & $\begin{array}{l}\text { Visualizing internal } \\
\text { processes or } \\
\text { mechanisms not visible }\end{array}$ & $\begin{array}{l}\text { Obscured Information Visualization, } \\
\text { Environment Adaptation and Gaze } \\
\text { POI are the basis for showing hidden }\end{array}$ & $\begin{array}{l}\text { Explain hidden features of } \\
\text { complex setups, can be } \\
\text { extended to allow for }\end{array}$ \\
\hline
\end{tabular}




\begin{tabular}{clll}
\hline \multicolumn{2}{c}{ to the eye. } & parts & interactivity and animation \\
\hline InteractableCheck & Interactable & InformationFilter \\
\hline InteractableCheck_RayCast
\end{tabular}

Figure 1: Pattern framework classes

We implemented a prototype based on concepts of the open source ARLearn system for mobile serious games [35], adapted for HMDs as a proof of concept. The patterns have been developed for the HoloLens, using the Unity game engine and the HoloToolkit [36]. Some of the patterns (Directed Gaze, Directed Movement, Gaze Cursor, Gesture-based Interaction, and Voice Commands) are already available in HoloLens, others were newly implemented in our prototype (figure 1, table 3 ).

Interactable, InteractableCheck_Gaze, and InteractableCheck_Position together form the basis for Point of Interest and Gaze Point of Interest. The scripts inheriting from InteractableCheck provide different ways of detecting Interactable objects. The EnvironmentRequirements class implements the pattern of the same name. Requirements consist of an environmental feature, an amount, and whether the amount represents an upper or lower limit. This data is compared to that gathered by the HoloLens to assess if the requirements defined on application level are met. EnvironmentRequirementGUI represents one way of visualizing the available information.

The spatial understanding features of the device are further utilized in SpatialUnderstandingSpawner, an implementation of Environment-Adaption which uses predefined sets of rules and constraints from SpawnInformation to find suitable spots for instantiating objects, e.g. on a wall or on a floor, far from the player. EnvironmentRequirementsFromUnderstandingSpawner provides a bridge between the two previous mechanisms by generating simple requirements from the parameters of a SpatialUnderstandingSpawner.

In first internal usability tests we could show the general functionality and operability of the patterns. In a next step, we aim to integrate the patterns into the general expertise-training framework of the WEKIT architecture [34].

Table 3. Implemented Patterns

\begin{tabular}{|c|c|c|}
\hline Pattern & Implementation & Comments \\
\hline $\begin{array}{l}\text { Point of } \\
\text { Interest, } \\
\text { Gaze POI }\end{array}$ & $\begin{array}{l}\text { Interactable, InteractableCheck_Gaze, and } \\
\text { InteractableCheck_Position }\end{array}$ & $\begin{array}{l}\text { The scripts inheriting from } \\
\text { InteractableCheck provide different } \\
\text { ways of detecting Interactable objects. }\end{array}$ \\
\hline $\begin{array}{l}\text { Environment } \\
\text { Requirements }\end{array}$ & $\begin{array}{l}\text { EnvironmentRequirements } \\
\text { EnvironmentRequirementGUI represents one } \\
\text { way of visualizing the available information }\end{array}$ & $\begin{array}{l}\text { Consist of an environmental feature } \\
\text { and an upper or lower limit. This is } \\
\text { assessed against data from HoloLens. }\end{array}$ \\
\hline $\begin{array}{l}\text { Environemnt } \\
\text { Adaptation }\end{array}$ & $\begin{array}{l}\text { Spatial understanding features are utilized in } \\
\text { SpatialUnderstandingSpawner }\end{array}$ & $\begin{array}{l}\text { Uses predefined sets of rules and } \\
\text { constraints from SpawnInformation to } \\
\text { find spots for instantiating objects, e.g. } \\
\text { on a wall/floor, far away. }\end{array}$ \\
\hline $\begin{array}{l}\text { Information } \\
\text { Filter }\end{array}$ & $\begin{array}{l}\text { InformationFilter executes tasks based on } \\
\text { data from InformationFilterMetric-derived } \\
\text { classes, such as IFMetric_Distance (distance } \\
\text { between object and player). }\end{array}$ & $\begin{array}{l}\text { The Information Filtering pattern } \\
\text { performs actions according to different } \\
\text { levels of proximity to the user, but can } \\
\text { be extended to cover other metrics. }\end{array}$ \\
\hline
\end{tabular}




\section{Conclusions}

We presented an overview of AR definitions, approaches, and applications. We highlighted approaches towards specifying design patterns and created a framework of design patterns for AR games, provided ideas towards the construction of games based on these patterns, and exemplarily adapted a sample of them for Microsoft's Hololens using the Unity game engine.

The work reported here can be expanded in several ways. The framework only covers a fraction of AR interactions, as the scope was limited to user interaction and usability with the Microsoft HoloLens, and it is likely not complete. The results can be seen as a proof of concept. Although focused on learning games, the framework can be used in other AR contexts such as commercial applications, learning applications, or simulations, which aim to make use of AR. Consequently, we see the main contribution of this paper to be a step towards broadening the understanding of AR interaction and application development based on design patterns. As next steps, we aim to apply the framework to the WEKIT AR training solution and to evaluate in pilot application cases related to aircraft maintenace, medical equipment operations, and space craft subsystem integration [34]. Based on these evaluation, we aim to further develop the framework to cover a broad range of AR use cases and interaction scenarios.

Acknowledgments. Parts of this work were supported by the European Commission under the Horizon 2020 Programme under grant agreement No 687669 (WEKIT).

\section{References}

1. Lamantia, J.: Inside Out: Interaction Design for Augmented Reality.

2. Papagiannakis, G., Singh, G., Magnenat-Thalmann, N.: A survey of mobile and wireless technologies for augmented reality systems. (2008).

3. FitzGerald, E., Ferguson, R., Adams, A., Gaved, M., Mor, Y., Thomas, R.: Augmented reality and mobile learning: the state of the art. Int. J. Mob. Blended Learn. 5, 43-58 (2013).

4. Calo, R., Denning, T., Friedman, B., Kohno, T., Magassa, L., McReynolds, E., Newell, B.C., Roesner, F., Woo, J.: Augmented Reality: A Technology and Policy Primer. (2015).

5. Ternier, S., De Vries, F., Börner, D., Specht, M.: Mobile augmented reality with audio, supporting fieldwork of Cultural Sciences students in Florence. In: Eleftherakis, G., Hinchey, M., and Holcombe, M. (eds.) Software Engineering and Formal Methods Proceedings of 10th International Conference, SEFM 2012. pp. 367-379. Springer (2012).

6. Benko, H., Holz, C., Sinclair, M., Ofek, E.: NormalTouch and TextureTouch : Highfidelity 3D Haptic Shape Rendering on Handheld Virtual Reality Controllers. In: Proceedings of the 29th Annual Symposium on User Interface Software and Technology. pp. 717-728. ACM (2016).

7. Johnson, L., Smith, R., Willis, H., Levine, A., Haywood, K.: The 2011 Horizon Report. The New Media Consortium, Austin, Texas (2011).

8. Munnerley, D., Bacon, M., Wilson, A., Steele, J., Hedberg, J., Fitzgerald, R.: Confronting an augmented reality. Res. Lerning Technol. 20, 39-48 (2012).

9. You, S., Neumann, U.: Fusion of Vision and Gyro Tracking for Robust Augmented Reality Registration. (2001).

10. Wetzel, R., McCall, R., Braun, A.-K., Broll, W : Guidelines for Designing Augmented Reality Games. In: Proceedings of the 2008 Conference on Future Play: Research, Play, Share. pp. 173-180 (2008). 
11. Schall, G., Wagner, D., Reitmayr, G., Taichmann, E., Wieser, M., Schmalstieg, D., Hofmann-Wellenhof, B.: Global Pose Estimation using Multi-Sensor Fusion for Outdoor Augmented Reality. In: Proceedings of the 2009 8th IEEE International Symposium on Mixed and Augmented Reality. pp. 153-162 (2009).

12. Furmanski, C., Azuma, R.T., Daily, M.: Augmented-reality visualizations guided by cognition: Perceptual heuristics for combining visible and obscured information. In: Proceedings of the International Symposium on Mixed and Augmented Reality (ISMAR'02). IEEE (2002).

13. Spatial mapping,

https://developer.microsoft.com/enus/windows/holographic/spatial_mapping.

14. Borchers, J.O.: A Pattern Approach to Interaction Design. AI Soc. 15, 359-376 (2001).

15. Björk, S., Lundgren, S., Holopainen, J.: Game Design Patterns. In: Level Up: Digital Games Research Conference 2003 (2003).

16. Wetzel, R.: A Case for Design Patterns supporting the Development of Mobile Mixed Reality Games. Found. Digit. Games. (2013).

17. Henderson, S.J., Feiner, S.: Evaluating the benefits of augmented reality for task localization in maintenance of an armored personnel carrier turret. In: IEEE International Symposium on Mixed and Augmented Reality 2009. pp. 135-144. IEEE (2009).

18. Olshannikova, E., Ometov, A., Koucheryavy, Y., Olsson, T.: Visualizing Big Data with augmented and virtual reality: challenges and research agenda. J. Big Data. 2, (2015).

19. Niantic: Pokémon GO. Game [Android]. (6 July 2016). Niantic, San Francisco, CA. Played August 2016., (2016).

20. Niantic: Ingress. Game [Android]. (14 December 2013). Niantic, San Francisco, CA. Played July 2016., (2013).

21. Kors, M.J.L., Ferri, G., van der Spek, E.D., Ketel, C., Schouten, B.A.M.: A Breathtaking Journey. Proc. 2016 Annu. Symp. Comput. Interact. Play - CHI Play '16. 91-104 (2016)

22. Specht, M., Ternier, S., Greller, W.: Dimensions of Mobile Augmented Reality for Learning: A First Inventory. J. Res. Cent. Educ. Technol. 7, 117-127 (2011).

23. Schmitz, B., Klemke, R., Specht, M.: Mobile gaming patterns and their impact on learning outcomes: A literature review. In: Ravencroft, A., Lindstaedt, S., Kloos, C.D., and Hérnandez-Leo, D. (eds.) 21st Century Learning for 21st Century Skills Proceedings of the 7th European Conference of Technology Enhanced Learning, ECTEL 2012, Lecture Notes in Computer Science. pp. 1-6. Springer, Saarbrüicken, Germany (2012).

24. Dunleavy, M.: Design Principles for Augmented Reality Learning. TechTrends. 58, 28-34 (2014).

25. Antonaci, A., Klemke, R., Specht, M.: Towards Design Patterns for Augmented Reality Serious Games. In: The Mobile Learning Voyage - From Small Ripples to Massive Open Waters. pp. 273-282 (2015).

26. McGee, K.: Patterns and Computer Game Design Innovation. In: Proceedings of the 4th Australasian conference on Interactive entertainment. RMIT University (2007).

27. Björk, S., Holopainen, J.: Patterns in Game Design. (2005).

28. Kreimeier, B.: The Case For Game Design Patterns, (2002).

29. Zagal, J.P., Mateas, M., Fernández-Vara, C., Hochhalter, B., Lichti, N.: Towards an Ontological Language for Game Analysis. In: Proceedings of DiGRA 2005 Conference. pp. 3-14 (2005).

30. Carvalho, M.B., Bellotti, F., Berta, R., De Gloria, A., Sedano, C.I., Hauge, J.B., Hu, J., Rauterberg, M.: An activity theory-based model for serious games analysis and conceptual design. Comput. Educ. 87, 166-181 (2015).

31. Schmitz, B., Klemke, R., Specht, M.: An Analysis of the Educational Potential of Augmented Reality Games for Learning. In: Specht, M. and Multisilta, J. (eds.) Proceedings of the 11th International Conference on Mobile and Contextual Learning 2012. pp. 140-147. , Helsinki, Finland (2011).

32. Sharma, P., Wild, F., Klemke, R., Helin, K., Azam, T.: D3.1 Requirement analysis and sensor specifications - First version, (2016).

33. Azuma, R.T., Baillot, Y., Behringer, R., Feiner, S., Julier, S., MacIntyre, B.: Recent 
advances in augmented reality. IEEE Comput. Graph. Appl. 21, 34-47 (2001).

34. Klemke, R., Limbu, B., Rasool, J.: WEKIT Framework \& Training Methodology First version. (2016)

35. Ternier, S., Klemke, R., Kalz, M., Specht, M.: ARLearn: augmented reality meets augmented virtuality. J. Univers. Comput. Sci. - Technol. Learn. across Phys. virtual spaces [Special issue]. 18, 2143-2164 (2012).

36. Microsoft: HoloToolkit, https://github.com/Microsoft/HoloToolkit. 